Published online on the journal's website:

http://jurnal.iailm.ac.id/index.php/mutawasith

\title{
Konsep Perlindungan Nasab dalam Perspektif Hukum Islam
}

\author{
Reza Pahlevi Dalimunthe, Restu Ashari Putra, Rizal Abdul Gani
}

Universitas Islam Negeri Sunan Gunung Djati Bandung, Indonesia JL. A.H Nasution No. 105 Cibiru, Bandung, Jawa Barat ashariputra48@gmail.com, rizal.agani28@gmail.com

\begin{tabular}{|c|c|c|}
\hline Received: & Revised: & Published: \\
\hline 28-02-2021 & 02-06-2021 & 05-07-2021 \\
\hline \multicolumn{2}{|c|}{ DOI: https://doi.org/10.47971/mjhi.v4i1.304 } \\
\hline
\end{tabular}

\begin{abstract}
Benefit as the core of maqâshid al-syariah has an important role in the development of Islamic law. Because Islamic law was revealed with the aim of presenting the benefit of humans, both in this world and in the hereafter. One of the benefits that are protected is the protection of lineage. Nasab is human nature, because humans have the instinct to regenerate. On the other hand, humans have the nature of obedience to God. So that the two natures accumulate in lineage protection. Lineage protection is concerned with quantity on the one hand, and quality on the other. The exact point proportions of the two are seen from the bounded realm of reality. Lineage protection is not only about regeneration, but also includes all intermediaries (wasilah) that support it, both in terms of quantity and quality. The purpose of this study is to find out what things can damage the lineage, such as adultery, incest marriage, prostitution and so on. Keywords: argument, keeping lineage
\end{abstract}

\section{Abstrak}

Kemaslahatan sebagai inti dari maqâshid al-syariah memiliki peranan penting dalam pengembangan hukum Islam. Sebab hukum Islam diturunkan dengan tujuan untuk menghadirkan kemaslahatan manusia, baik di dunia maupun di akhirat. Salah satu kemaslahatan yang diayomi adalah perlindungan nasab. Nasab adalah fitrah manusia, karena manusia memiliki naluri beregenerasi. Di sisi lain, manusia memiliki fitrah kepatuhan kepada Tuhan. Sehingga dua fitrah tersebut terakumulasi pada perlindungan nasab. Perlindungan nasab berkenaan dengan kuantitas di satu sisi, dan kualitas di sisi lain. Proporsional titik yang tepat dari keduanya dilihat dari lingkup realitas yang terikat. Perlindungan nasab tidak hanya pada regenerasi saja, tapi juga mencakup pada segala perantara (wasilah) yang menunjangnya, baik pada kuantitas maupun kualitas. Tujuan penelitian ini adalah untuk mengetahui hal apa-apa saja yang dapat merusak nasab, seperti perzinahan, pernikahan sedarah, pelacuran dan sebagainya.

Kata Kunci: dalil, menjaga nasab

\section{A. PENDAHULUAN}

Syariat adalah hukum Allah SWT yang mencakup segala hal. Dengan kata kunci bahwa syariat hadir untuk kemaslahatan manusia, baik di dunia maupun akhirat. ${ }^{1}$ Persoalan realitas kehidupan terus berkembang, maka upaya kemaslahatan tersebut juga turut berkembang. Hingga saat ini, persinggungan antara syariat dengan maslahat realitas tersebut banyak dibicarakan oleh pakar, khususnya kajian keislaman maqashid syariah. Persinggungan syariat dan realitas merupakan suatu

\footnotetext{
${ }^{1}$ Abu Ishaq As-Syatibi, al-Muwafaqat fi Ushul as-Syariah (Beirut: Dar Kotob Ilmiyah, 2004 ), hal. 7.
} 
yang pasti. Karena syariat seharusnya lahir dari proses integrasi dialektik antara nas, akal dan realitas. ${ }^{2}$ Hukum- hukum pada syariat itu tidaklah dibuat untuk hukum itu sendiri, melainkan dibuat untuk tujuan lain yaknikemaslahatan. ${ }^{3}$

Semua perintah dan larangan Allah yang terdapat dalam Al-Quran, begitu pula perintah dan larangan Nabi Muhammad SAW yang ada dalam Hadits, yang diasumsikan ada keterkaitan dengan hukum memberikan kesimpulan bahwa semuanya mempunyai tujuan tertentu dan tidak ada yang sia-sia. Semuanya mempunyai hikmah yang mendalam, yaitu sebagai rahmat bagi umat manusia. ${ }^{4}$

Persoalan lain yang muncul adalah implikasi hukum dan social yang melekat pada anak tersebut. Anak-anak hasil hubungan yang tidak sah sering kali turut menanggung akibat dari oerbuatan kedua orang tuanya. Pelabelan negative dan deskriminatif, seperti sebutan anak haram, anak jadah, anak zina, anak tidak sah, anak semenak-menak, dan istilah lainnya yang seringkali dinisbatkan pada anak keturunanya. ${ }^{5}$

Penelitian ini bertujuan untuk memahami salah satu hikmah syariat berupa: perlindungan nasab, serta pengembangannya pada beberapa tema realitas kehidupan seperti perzinahan dan semua hal yang dapat merusak nasab.Ini dilakukan sebagai bentuk respon penguatan atas penelitian Mohamad Hafifi Bin Hassimdan Syamim Zakwan Bin Rosmanbertajuk "Analisis Hadis-Hadis Berkaitan Tuntutan Menjaga Nasab"yang dimuat dalam e-Proceeding of 3rd INHAD International Muzakarah \& Mu'tamar on Hadith (IMAM 2018)pada27 December 2018 di Selangor, Malaysia. Meski kasus-kasus dalam penelitian tersebut sesuai dengan konteks hukum di Negeri Jiran, namun secara umum argumentasi dalil naqli terutama hadits-hadits tidak disampaikan secara detil pada beberapa topic perusak nasab yang semua itu tetaplah sesuai dengan konteks Indonesia karena hukum syariat Islam yang rahmatanlilalamin.

\section{B. METODOLOGI}

Metode penelitian yang digunakan dalam penulisan ini adalah studi kepustakaan (library research), yaitu dengan pengumpulan data dan informasi dari al-Qur'an, kitabkitab fiqih, hadits, dan berbagai buku, literatur, catatan, serta laporan yang berkaitan dengan permasalahan yang dikaji, yaitu tentang konsep nasab.

Setelah data yang diperlukan terkumpul, baik dari sumber primer maupun sekunder, maka langkah selanjutnya adalah penganalisaan data-data tersebut dengan menggunakan metode analisa isi (content analysis), yaitu dengan meneliti isi pesan tertulis yang disampaikan dalam data-data tersebut secara mendalam, sehingga didapatkan informasi secara mendetail dan menyeluruh.

Kemudian informasi yang diperoleh tersebut disusun dengan menggunakan metode deskriptif kualitatif melalui pendekatan deskriptif normatif, yaitu suatu metode untuk menjelaskan ayat ayat al-Quran dengan mengacu kepada status hukum bahasan (tema) tertentu, dalam hal ini adalah tema konsep nasab. Caranya yaitu ayatayat al-Quran yang membicarakan satu topik masalah yang sama (nasab) tersebut dihimpun, kemudian disusun dan diberi keterangan dan penjelasan, lalu diambil kesimpulannya.

${ }^{2}$ Wahbah az-Zuhaily, Taghayyur Al-ljtihad (Damaskus: Darl al-Maktabi, 2000), hlm. 8 - 9

${ }^{3}$ Fathi Daryni, al-Manâhij al-Ushûliyyah fí ljtihâd bi al-Ra'yi fî al-Tasyrî' (Damaskus: Dâr al-Kitâb alHadits, 1975), hlm. 28

"Lihat: Ghafar Shidiq, "Teori Maqâshid Al-Syarî"ah Dalam Hukum Islam", Jurnal Sultan Agung, Vol XLIV No. 118 Juni-Agustus 2009, hlm. 120.

${ }^{5}$ Vol. 12, No. 2, Desember 2015: 357-375.

https://www.jurnalhunafa.org/index.php/hunafa/article/view/398. 


\section{HASIL PENELITIAN DAN PEMBAHASAN}

\section{Konsep Perlindungan Nasab}

Penjagaan nasab atau dalam istilah lain perlindungan, diistilahkan hifz an-nasl, pada berbagai literatur ada perbedaan penyebutan istilah mengenai perlindungan nasab ini. Ada yang menyebut kata nasl, ada kata nasab, ada pula yang menyebut kata budh'. ${ }^{6}$ Perbedaan dari tiga istilah tersebut adalah: a) nas/ berarti garis keturunan ke atas, misalnya ayah, ayahnya ayah, ayahnya ibu, dan seterusnya, b) nasab adalah garis keturunan ke bawah, anak, cucu, dan seterusnya, c) budh' berarti kelamin perempuan.

Dilihat dari makna masing-masing istilah yang digunakan, istilah yang paling tepat adalah istilah pertama (nas/). Karena muatan yang dilindungi pada dasarnya terletak pada garis keturunan. Kemaslahatan utama yang dilindungi syariat melalui poin ini adalah keberlangsungan suatu generasi manusia, untuk mencegahnya dari kepunahan, dengan upaya-upaya yang mengacu pada kebaikan di dunia dan akhirat. Dan maslahat tersebut tertuang lebih jelas pada istilah nasl, yang berarti keturunan. Sedangkan pada istilah nasab, gambaran yang dilihat adalah garis keturunan seseorang dari atas.

Hampir tidak ada kaitannya dengan maslahat yang dimaksud. Begitu pula dengan istilah budh' (alat kelamin), hampir tidak ada kaitan langsung dengan maslahat yang dimaksud, karena alat kelamin hanyalah sebagai sarana bagi keberlangsungan manusia. Karena itulah Ar- Raisuni menjelaskan penggunaan kata nas/ itu lebih baik dari kata nasab, karena nas/ adalah tujuannya dan nas/ pula yang mencapai level prioritas (dharuriyat) untuk dijaga, sedangkan nasab hanyalah bagian dari perantara untuk mencapai keterjagaan nasl. ${ }^{7}$

Hukum-hukum yang muncul dari perlindungan (penjagaan) nasab ini banyak sekali. Secara garis besar ada dua peninjauan,yaitu:

a. Menjaga eksistensi nas/ agar tetap berlangsung, dengan cara mengupayakan halhal yang memaksimalkan hadirnya keturunan yang baik dan ideal. Dari peninjauan pertama ini muncullah hukum-hukum syariat sepertiberikut:

1) Dianjurkannya menikah, memilih pasangan yang baik, menikahi perempuan yang berpotensi banyak melahirkan anak, diperbolehkannya poligami, dan lainnya.

2) Diwajibkannya bagi orang tua untuk mendidik anaknya, khususnya tentang prinsip-prinsip utama dalam Islam.

3) Dianjurkannya menjaga kesehatan alat reproduksi.

b. Menjaga nasl dari kerusakan yang menghampiri, dengan cara menghindarkan hal-hal yang membuat keturunan menjadi rusak, habis, dan tidak baik. Dari penijauan kedua ini dapat tergambar dengan melihat hukum-hukum seperti berikut:

1) Tidak dianjurkannya hidup tanpa menikah seterusnya, baik karena alasan untuk fokus ibadah ${ }^{8}$, maupun alasan yang lain.

${ }^{6}$ Saad al-Yubi melakukan penelusuran terhadap penggunaan tiga istilah tersebut: a) nasab digunakan oleh ar-Razi, Ibnu Qudamah, al-Baidhawi, al-Qarafi, Shadr Syariah al-Mahbubi, at-Tufi, alAshfihani, Ibnu Subki, Kamal bin Hammam, al-Mahalli, Ibnu Amir Hajj, Zakariya al-Anshari, Shahib alMuraqi, Ibnu Budran, dan Isa Mannun, b) nas/ digunakan oleh al-Ghazali, al-Amudi, Ibnul Hajib, Aduddin al-lji, az-Zarkasyi, as-Syatibi, Muhammad al-Futuhi, dan as-Syaukani, c) sedangkan budh' digunakan oleh Imam Haramain, Ibnu Taimiyah, dan al-Ghazali dalam Syifa al-Ghalil. Lihat: Muhammad Sa"ad al-Yubi, Maqashid as-Syariah al-Islamiyah wa Alaqatuha bi al-Adillah as-Syar'iyah (Riyad: Dar al-Hijrah, 1998), hal. 245-247.

${ }^{7}$ Ahmad Ar-Raisuni, Nadzariyat al-Maqashid Inda as-Syatibi (Riyad: an-Najah, 1411 H), hal. 42.

${ }^{8}$ Banyak hadis Nabi menjelaskan tentang ini, salah satunya hadis tentang tiga orang yang merasa jauh derajat Nabi, lantas akan fokus shalat, puasa, dan satu lagi tidak akan menikah. Nabi SAW pun menjawab, "Demi Allah, aku adalah orang yang paling takut dan takwa kepada Allah 
2) Diharamkannya penyalahgunaan seksual pada selain yang halal, seperti zina, sodomi, danlainnya.

3) Dilarangnya merusak alat reproduksi atau mengkonsumsi sesuatu sehingga menyebabkan tidak bisa memiliki anak, baik pada laki-laki maupun perempuan. ${ }^{9}$

4) Dilarang melakukan aborsijanin. ${ }^{10}$

\section{Hal-Hal yang Merusak Nasab}

\section{a. Perzinahan}

1. Pengertian Zina

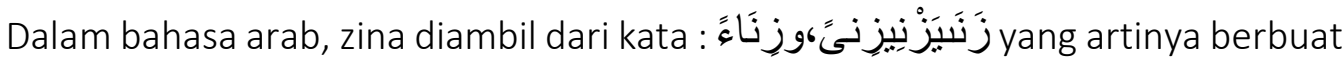
fajir (nista). Perbuatan zina termasuk ruang lingkup macam-macam fiqh jinayah. Zina adalah hubungan kelamin antara laki-laki dengan perempuan tanpa adanya ikatan perkawinan yang sah dan dilakukan dengan sadar serta tanpa adanya unsur syubhat. ${ }^{11}$ Delik perzinaan ditegaskan dalam al-Qur'an dan sunnah. Hukuman bagi pelaku zina yang belum menikah (ghairu muhsan) didasarkan pada ayat al-Qur'an, yakni didera seratus kali. Sementara bagi pezina muhsan dikenakan sanksi rajam. Rajam dari segi bahasa berarti melempari batu. Rajam adalah melempari pezina muhsan sampai menemui ajalnya. ${ }^{12}$

Zina adalah perbuatan yang sangat tercela dan pelakunya dikenakan sanksi yang amat berat, baik itu hukum dera maupun rajam, karena alasan yang dapat dipertanggungjawabkan secara moral dan akal. Kenapa zina diancam dengan hukuman berat. Hal ini disebabkan karena perbuatan zina sangat dicela oleh Islam dan pelakunya dihukum dengan hukuman rajam (dilempari batu sampai meninggal dengan disaksikan orang banyak), jika ia muhsan. Jika ia ghairu muhsan, maka dihukum cambuk 100 kali. Adanya perbedaan hukuman tersebut karena muhsan seharusnya bisa lebih menjaga diri untuk melakukan perbuatan tercela itu, apalagi kalau masih dalam ikatan perkawinan yang berarti menyakiti dan mencemarkan nama baik keluarganya, sementara ghairu muhsan belum pernah menikah. ${ }^{13}$

2. Dalil Al-Quran dan Hadits tentang Perzinahan

Hukum berzina adalah haram, keharaman zina Allah 楼 berfirman dalam QS. AlIsra' ayat 32 :

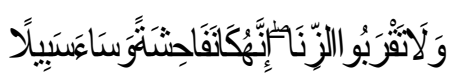

"Dan jangan kamu mendekati zina, sesungguhnya zina itu adalah perbuatan yang keji dan merupakan jalan yang buruk".

Keharaman zina juga banyak disampaikan melalui hadits-hadits Rasulullah diantaranya dari Abu Malik al Asy'ari bahwa dia mendengar Nabi shallallahu 'alaihi wasallam bersabda:

daripada kalian, tetapi aku berpuasa dan tidak, aku juga shalat dan tidur, aku juga menikahi beberapa perempuan. Menikah adalah sunahku, siapa yang enggan dengan sunahku, maka bukan bagianku." (HR. Bukhari Muslim)

${ }^{9}$ as-Syarqawi, Hasyiyah ala Tuhfah at-Tullab (Beirut: Darul Fikr, tt), juz. 2, hal. 332, al-Jamal, Hasyiyah ala al-Manhaj (Beirut: Darul Fikr, tt), juz. 4, hal. 447.

${ }^{10}$ Abdullah al-Bassam, Taudih al-Ahkam min Bulugh al-Maram (Mekkah, Penerbit al-Asadi, 2003), juz. 6, hal. 102, lihat juga: Ibnu Hajar al-Asqalani, Fath al-Bari bi Syarh al-Bukhari (Riyad, Penerbit Malik Fahd, 2001), juz.9, hal.220.

\footnotetext{
${ }^{11}$ Sayyid sabiq, Fiqh Sunnah, (Bandung: PT Al-Maarif, 1996), 86-87

${ }^{12}$ Ibid., 86-87

${ }^{13}$ Wahbah Zuhaili, Fiqh Imam Syafi'i, (Jakarta: Almahira, 2010), 340.
} 


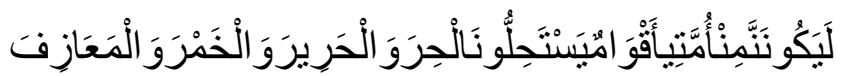

"Sungguh ada dari umatku beberapa kaum yang menghalalkan (menganggap halal perzinahan, sutera, minuman keras, dan musik-musik." (HR. Bukhari).

1. Hukuman Pelaku Zina Ghairu Muhshan

Seseorang yang melakukan zina Ghairu muhshan yaitu mereka yang belum menikah baik lelaki atau perempuan wajib dikenakan ke atas mereka hukuman cambuk 100 kali cambuk dan di buang atau diasingkan selama setahun sebagaimana terdapat dalam firman Allah AWT dalam surat An-Nur ayat 2 yang berbunyi:

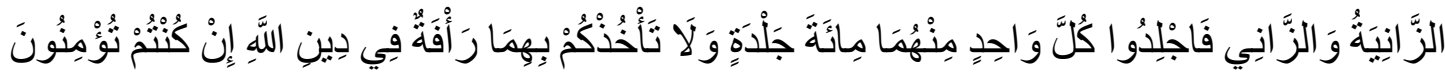

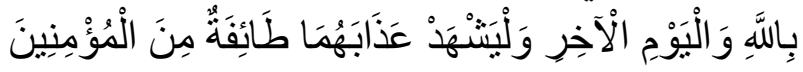

"Pezina perempuan dan laki-laki hendaklah dicambuk seratus kali dan janganlah merasa belas kasihan kepada keduanya sehingga mencegah kamu dalam menjalankan hukum Allah, hal ini jika kamu beriman kepada Allah dan hari akhir. Dan hendaklah dalam menjatuhkan sanksi (mencambuk) mereka disaksikan oleh sekumpulan orang-orang yang beriman. ${ }^{14}$

Rasulullah bersabda :

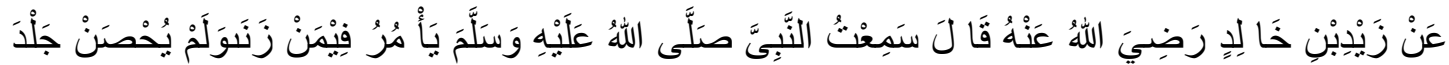

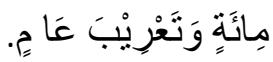

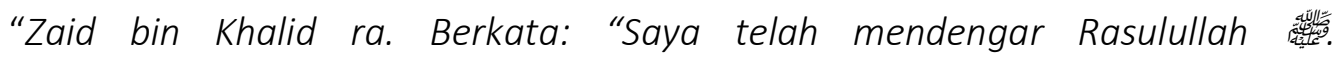
memerintahkan supaya orang yang zina ghairu muhshan didera seratus kali dan dibuang satu tahun" ( H.R. Bukhari )

\section{Hukuman Pelaku Zina Muhshan}

Zina mukhshan yaitu zina yang dilakukan orang yang pernah terikat tali ikatan perkawinan, artinya yang dilakukan baik suami, isteri, duda atau janda. Hukuman (had) bagi pelaku zina muhshan, yaitu dirajam atau dilempari batu sampai ia mati. Sebagaimana sabda Nabi :

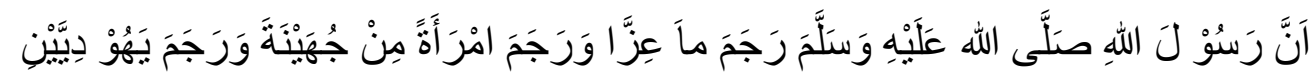

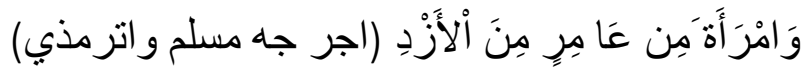

"Sesungguhnya Rasulullah merajam seseorang yang bernama Ma'iz dan merajam seorang perempuan dari kabilah Juhainah serta merajam pula dua orang Yahudi dan seorang perempuan dari kabilah Amir dari suku Azd" ( H.R. Muslim dan Tirmidzi )

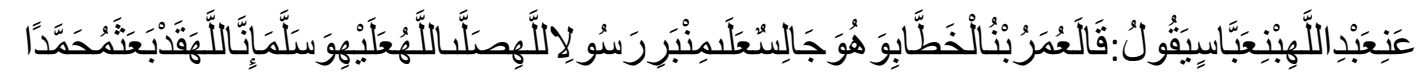

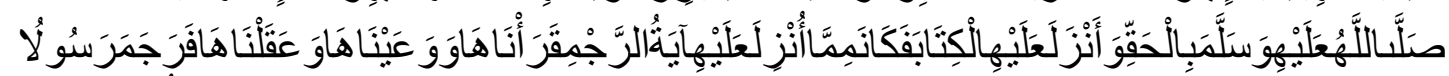

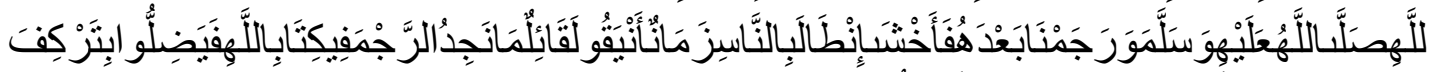

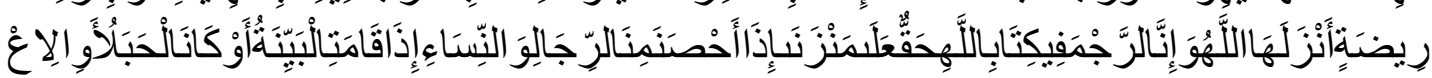

Dari Abdullah bin 'Abbas, dia berkata, Umar bin Al Khaththab berkata, sedangkan beliau duduk di atas mimbar Rasulullah Shallallahu 'alaihi wa sallam-, "Sesungguhnya Allah telah mengutus Muhammad Shallallahu 'alaihi wa sallam dengan

${ }^{14}$ Fauzan al-Anshari Abdurrahman Madjrie, Hukuman Bagi Pezina dan Penuduhnya, (Jakarta: Kahirul Bayan, 2002), hal 6. 
membawa al haq, dan menurunkan Al Kitab (Al Qur'an) kepadanya. Kemudian diantara yang diturunkan kepada beliau adalah ayat rajam. Kita telah membacanya, menghafalnya, dan memahaminya. Rasulullah Shallallahu 'alaihi wa sallam telah melaksanakan (hukum) rajam, kitapun telah melaksanakan (hukum) rajam setelah beliau (wafat). Aku khawatir jika zaman telah berlalu lama terhadap manusia, akan ada seseorang yang berkata, 'Kita tidak dapati (hukum) rajam di dalam kitab Allah', sehingga mereka akan sesat dengan sebab meninggalkan satu kewajiban yang telah diturunkan oleh Allah. Sesungguhnya (hukum) rajam benar-benar ada di dalam kitab Allah terhadap orang yang berzina, padahal dia telah menikah, dari kalangan laki-laki dan wanita, jika bukti telah tegak (nyata dengan empat saksi, red.), atau terbukti hamil, atau pengakuan.

\section{b. Pernikahan Sedarah}

1. Pengertian Nikah

Kata nikah berasal dari bahasa Arab yakni نحكاح yang merupakanmasdar dari kata kerja نكح : نزوج Semudianditerjemahkan ke dalam bahasa Indonesia sebagai perkawinan. Kata nikahsering kita gunakan sebab telah masuk ke dalam bahasa Indonesia. ${ }^{15}$ Secara bahasa, kata nikah berarti adh-dhammu wattadaakhul (bertindih dan memasukkan). Dalam kitab lain, kata nikah diartikan dengan adh- dhammu waljam'u (bertindih danberkumpul). ${ }^{16}$ Pemakaian termasyhur untuk kata nikah adalah tertuju pada akad. Dan sesungguhnya inilah yang dimaksud pembuat Syari'at. Didalam Al-Qur'an pun kata nikah tidak dimaksudkan lain kecuali arti akad perkawinan.

Adapun secara istilah ilmu Fiqih, nikah berarti suatu akad (perjanjian) yang mengandung kebolehan melakikan hubungan seksual dengan memakai kata-kata (lafazh) nikah atau tazwij. Menurut undang-undang perkawinan No. 1 Tahun 1974 menyebutkan bahwa perkawinan adalah ikatan lahir batin antara seorang laki-laki dengan seorang perempuan sebagai suami istri dengan tujuan membentuk keluarga (rumah tangga) yang bahagia dan kekal berdasarkan Ketuhanan Yang Maha Esa. ${ }^{17}$ Dalam Kompilasi Hukum Islam mendefenisikan yaitu akad yang sangat kuat atau mitsaqan ghalizhan untuk mentaati perintah Allah dan melaksanakannya merupakan ibadah.

\section{Pengertian dan Hukum Nikah Sedarah}

Pernikahan sedarah atau disebut juga pernikahan senasab adalah perkawinan yang di lakukan antara seorang wanita dan seorang laki-laki yang masih memiliki hubungan darah yang sangat dekat. Allah 遴. mengharamkan mengawini perempuan-perempuan yang ada hubungan, mahram, baik karena nasab, susuan ataupun semenda. Larangan perkawinan ini berlaku untuk selama-lamanya dalam arti sampai kapan pun dan dalam keadaan apa pun laki-laki dan perempuan itu tidak boleh melakukan perkawinan.Larangan dalam bentuk ini disebut dengan mahram muabbad.

Allah SWTberfirman dalam Al Quran Surat An Nisa ayat 23 :
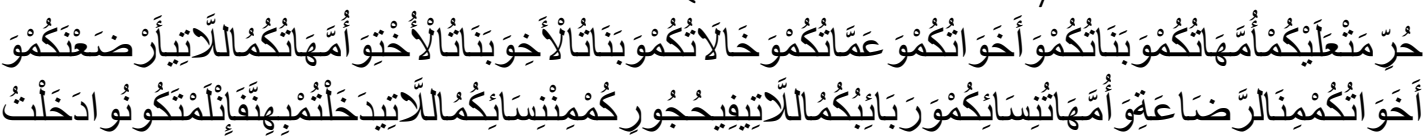

${ }^{15} \mathrm{H}$. Muhammad Yunus, Kamus Bahsaa Arab-Indonesia (Jakarta: PT. Hidakarya Agung, 1989). H.

467

${ }^{16}$ Rahmat Hakim, Hukum perkawinan Islam, (Bandung: Pustaka Setia, 2000), h. 11

${ }^{17}$ Undang-Undang Perkawinan No 1, Tahun 1974 dan Penjelasannya PP. No 9 Tahun 1975 (Semarang: Aneka IImu, 1990) Cet. ke-1, h. 1 
"Diharamkan atas kamu (menikahi) ibu-ibumu, anak-anak perempuanmu, saudara-saudara perempuanmu, saudara-saudara perempuan ayahmu, saudara-saudara perempuan ibumu, anak-anak perempuan dari saudara lakilakimu, anak-anak perempuan dari saudara perem-puanmu, ibu-ibu yang menyusuimu, saudara-saudara perempuan yang satu susuan denganmu, ibu-ibu isterimu (mertua), anak-anak perempuan dari isterimu (anak tiri) yang dalam pemeliharaanmu dari isteri yang telah kamu campuri, tetapi jika kamu belum mencampurinya (dan sudah kamu ceraikan) maka tidak berdosa atasmu (jika menikahinya), (dan diharamkan bagimu) isteri-isteri anak kandungmu (menantu), dan (diharamkan) mengumpulkan (dalam pernikahan) dua perempuan yang bersaudara, kecuali yang telah terjadi pada masa lampau. Sungguh, Allah Maha Pengampun, Maha Penyayang."

Dalam ayat ini Allah SWT menyebutkan siapa-siapa saja yang haram untuk dinikahi/ mahram dan diantaranya adalah saudara sedarah. Perkawinan sedarah juga diketahui berpotensi menimbulkan dampak besar terutama terhadap anak-anak. Selain mengakibatkan anak terlahir cacat mental/fisik, anak tersebut secara tidak langsung mendapat kerugian baik secara spiritual ataupun materiil yaitu tentang status atau kedudukannya didalam negara dan agama.

\section{c. Pelacuran}

Pelacuranatauprostitusiadalahperilaku bebas yang tidak dapat terkontrol terkait hawa nafsu dengan hubungan badan yang dilakukan bukan dengan orang yang sah secara hukum negara ataupun agama serta tidak mengenal batas-batas kesopanan. Hal tersebut terjadi di hampir semua negara baik itu negara timur maupun barat dan menjadi masalah sosial. Aktivitas asusila ini bahkan sudah terjadi dengan pola yang pada umumnya sama sejak dahulu kala. ${ }^{18}$

Pelaku prostitusi menggunakan badannya sebagai sumber pendapatannya dengan memuaskan hasrat seksual.Seringkali motif prilakuiniterjadi di masyarakat Sebagian besar atas dasar motif ekonomi. Dalam kasus Indonesia, Akar kata prostitusi sendiri berasal dari bahasa latinpro-stituere atau pro-stauree yang berarti membiarkan diri berbuat zina, melakukan persundalan, percabulan dan pergendakan. Sedangkan prostitute adalah pelaku prostitusi yang di Indonesia disebut dengan istilah WTS (wanita tuna susila) atau PSK (pekerja seks komersil).

Dalam penelitian ini tidak dijelaskan bagaimana dalil-dalil dari Al-Quran dan terutama hadits nabi menjelaskan soal ini. Islam menguraikan dalil perbuatan prostitusi sebagai sebuah tindakan yang mendekati zina.

Dan janganlah kamu mendekati zina; Sesungguhnya zina itu adalah suatu perbuatan yang keji. dan suatu jalan yang buruk.(Al-Isra: 32)

Hadits nabi menjelaskan dosa dari perbuatan zina adalah dosa besar setelah syirik (menyekutukan Allah) dan dosa membunuh anak kandung karena takut miskin.

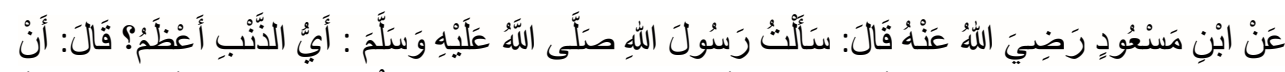

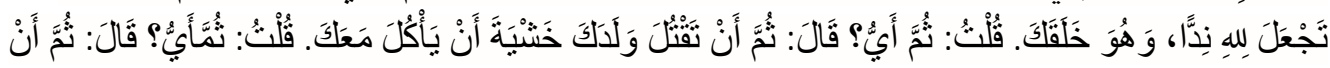

${ }^{18}$ Di AjengLaily H, Lentera, Vol. XVIII, No. 2, 2016 
Dari 'Abdullah bin Mas'ûd Radhiyallahu anhu ia berkata, "Aku bertanya kepada Rasûlullâh Shallallahu 'alaihi wa sallam, 'Dosa apakah yang paling besar?' Beliau Shallallahu 'alaihi wa sallam menjawab, "Engkau menyekutukan Allâh padahal Dia yang telah menciptakanmu." Kemudian aku bertanya lagi, 'Kemudian dosa apa lagi?' Beliau Shallallahu 'alaihi wa sallam menjawab, "Engkau membunuh anakmu karena takut ia makan bersamamu." Aku bertanya lagi, 'Kemudian dosa apa lagi?' Beliau Shallallahu 'alaihi wa sallam pun menjawab, "Engkau berzina dengan istri tetanggamu."

Hadits ini shahih. Diriwayatkan oleh al-Bukhâri (no. 4477, 6001, 6811, 6861, 7520, 7532); Muslim (no. 86); At-Tirmidzi (no. 3182), dan an-Nasa`i (VII/89-90). Dalam riwayat al-Bukhâri dan Muslim ada tambahan bahwa Allâh Azza wa Jalla membenarkan perkataan Nabi Shallallahu 'alaihi wa sallam dengan firman-Nya:

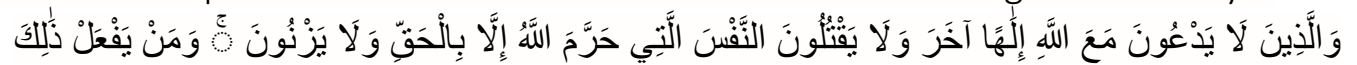
يَلْقَ أَثَامًا

Dan orang orang yang tidak mempersekutukan Allâh dengan sembahan lain dan tidak membunuh jiwa yang diharamkan Allâh kecuali dengan (alasan) yang benar, dan tidak berzina dan barangsiapa yang melakukan demikian itu, niscaya dia mendapat hukuman yang berat. [Al-Furqân:68]

Dalam pemberian hukum atas pelaku pelacuran ini sebagaimana aktivitas zina, Rasulullah SAW juga sangat mempertimbangkan sejumlah faktor. Dalam salah satu Riwayat diungkapkan ketika Ma'iz bin Malik datang kepada Rasul dan mengakui telah berbuat zina. Namun Rasulullah SAW tidak lantas menghukumnya sebelum melalui proses-proses yang sangat ketat. Rasululullah baru menjatuhkan hukuman setelah melakukan proses pemeriksaan fisik, mental, pengetahuan dan status perkawinan barulah Rasulullah menentukan hukum rajam.

Asy-Syaibanimengatakan, "Aku bertanya kepada Abdullah bin Aufa, "Apakah Rasulullah merajam?" Iamenjawab: 'Ya' Aku (Asy-Syaibani) berkata, "Sebelum surat AnNur atau sesudahnya?" dia berkata (Abdullah bin Aufa) berkata, "Akutidaktahu."

Surat An-Nur yang dimaksud adalah ayat 2, "Perempuan yang berzina dan lakilaki yang berzina, Maka deralah tiap-tiap seorang dari keduanya seratus kali dera, dan janganlah belas kasihan kepada keduanya mencegah kamu untuk (menjalankan) agama Allah, jika kamu beriman kepada Allah, dan hari akhirat, dan hendaklah (pelaksanaan) hukuman mereka disaksikan oleh sekumpulan orang-orang yang beriman."

Sanksi diberikan kepada pelaku zina juga harus memenuhi persyaratan yakni merdeka, baligh dan berakal. Tidak ada had zina bagi anak kecil yang belum baligh dan orang gila. Perbedaan hukuman juga diberikan nabi bagi mereka yang belum berada dalam ikatan pernikahan. Persyaratan ini diutarakan Rasulullah SAW dalam salah satu hadis:

Dari Abu Hurairah RA, bahwa Rasulullah SAW memutuskan hukum bagi yang berzina dan belum menikah dengan mengasingkan selama setahun, dan melaksanakan hukum had atas dirinya.

Selain itu pelaku hanya dapat dihukum jika mengetahui bahwa zina adalah haram dan tidak dipaksa dengan paksaan mulji'an yaitu paksaan yang dapat membahayakan jiwa atau anggota tubuhnya. 


\section{d. Muncikari}

Aktivitas perzinahan yang dilakukan demi kepentingan pemuasan hawa nafsu telah berlangsung secara terang-terangan dengan cara-cara transaksional ekonomi. Aktivitas yang dalam kasus Indonesia difasilitasi oleh seorang germo atau muncikari jelas adalah perbuatan dosa besar. Dalam Kamus Besar Bahasa Indonesia (KBBI), dijelaskan bahwa germo atau muncikari adalah induk semang bagi perempuan lacur. Pelacuran merupakan perbuatan maksiat atau dosa, sehingga mempekerjakan orang untuk berbuat maksiat pada hakikatnya juga adalah perbuatan dosa.

"Tolong menolonglah kamu dalam mengerjakan kebajikan dan taqwa, dan jangan tolong menolong dalam berbuat dosa dan permusuhan ..." [QS. al-Maidah (5): 2].

Dari 'Ubadah bin Shamit (diriwayatkan) ia berkata, Rasulullah SAW bersabda, ikutilah semua ajaranku, ikutilah semua ajaranku. Sungguh, Allah telah menetapkan hukuman bagi mereka (kaum wanita), perjaka dengan perawan hukumannya adalah cambuk seratus kali dan diasingkan selama setahun, sedangkan laki-laki dan wanita yang sudah menikah hukumannya adalah dera seratus kali dan dirajam [HR. Muslim: 3199].

Meski memberi fasilitas kepada aktivitas terjadinya perzinahan, namun muncikari tidak termasuk, dalam hukum pidana Islam, yang dihukum dengan kategori qishash dan diyat, juga tidak termasuk dalam Hudud. Aktivitas muncikari masuk ke dalam kategori takzir yakni tindak pidana yang hukumannya diserahkan kepada penguasa atau pemerintah dalam suatu tempat atau negara, untuk menjatuhkan hukuman yang seadil-adilnya, dari yang seringan-ringannya sampai dengan yang seberat-beratnya berupa hukuman mati.

\section{KESIMPULAN}

Islam sebagai agama yang memiliki karakter rahmatan lil alamin tentunya memberikan perhatian lebih terutama dalam bidang pengaturan anak keturunan, bahkan masuk dalam salah satu tujuan maqashid syariah, yakni hifzhul al-nasl, yang artinya menjaga keturunan. Dalam tinjuan hukum Islam, konsep perlidungan atau penjagaan anak keturunan dalam diupayakan dengan cara menghindari praktik-praktik yang dapat merusak keturunan (nasab), diantaranya: perzinahan, perkawinan sedarah, pelacuran, dan mucikari. Sehingga dalam perspektif hukum Islam keempat praktik tersebut status hukumnya adalah haram.

\section{DAFTAR PUSTAKA}

Abdullah al-Bassam.Taudih al-Ahkam min Bulugh al-Maram. Mekkah, Penerbit alAsadi, 2003.

Abu Ishaq As-Syatibi.al-Muwafaqat fi Ushul as-Syariah. Beirut: Dar Kotob Ilmiyah, 2004.

Ahmad Ar-Raisuni.Nadzariyat al-Maqashid Inda as-Syatibi. Riyad: an-Najah, $1411 \mathrm{H}$

Di AjengLaily H, PenanggulanganProstitusiPerspektifHadits, Lentera,Vol. XVIII, No. 2, 2016.

Fathi Daryni.al-Manâhij al-Ushûliyyah fî ljtihâd bi al-Ra'yi fî al-Tasyrî́ (Damaskus: Dâr al-Kitâb al- Hadîts, 1975. 
Ghafar Shidiq. "Teori Maqâshid Al-Syarî"ah Dalam Hukum Islam”, Jurnal Sultan Agung, Vol XLIV No.118 Juni-Agustus 2009.

Muhammad Yunus, Kamus Bahsaa Arab-Indonesia. Jakarta: PT. Hidakarya Agung, 1989.

Rahmat Hakim. Hukum perkawinan Islam. Bandung: Pustaka Setia, 2000.

Sayyid Sabiq. Fiqh Sunnah. Bandung: PT Al-Maarif, 1996.

Wahbah az-Zuhaily.Taghayyur Al-ljtihad. Damaskus: Darl al-Maktabi, 2000.

Wahbah Zuhaili, Fiqh Imam Syafi'i. Jakarta: Almahira, 2010. 